\title{
Gender factor in the structure and conduct of the cocoa industry in Nigeria
}

\author{
G.O. Akinola \\ Department of Management and Accounting, Obafemi Awolowo University, \\ Ile-Ife, Osun State, Nigeria \\ gakinola@oauife.edu ng; gakinola2002@yahoo.com \\ Received September 2004
}

\begin{abstract}
The study examined gender differentiation of tasks and responsibilities and evaluated the level of success and/ or failure among men and women in cocoa marketing in the study area using primary and secondary data collection.

The study revealed that there was gender discrimination against women in access to credit due to their inability to provide collateral security. It was also found that the major marketing problems faced by cocoa marketers included those of pricing, finance, transportation, activities of fraudsters and high cost of marketing. The study also revealed that the structure of the industry did not seem to have contributed to the observed barriers to entry features. The problems preventing new entrants into the industry within the past few years included those of transportation, unstable price (unforeseen fall in Cocoa prices), access to loan or problems created by banks by charging what was considered to be too high bank interest rates on loan. These are without prejudice to their volume of trading.
\end{abstract}

The study concluded that female cocoa marketers in Ondo State possessed tremendous ability to succeed in the business if only their opportunities to credit facilities and capital could be enhanced.

\section{Introduction}

Women are found to contribute significantly to economic production in almost all societies; their contribution to agricultural production is even greater than that of men (FOS, 1997). In retail trading, cottage industries and service occupations, women have continued to play significant roles. The contribution that women make to the http://www.usaid.gov/our_work/cross-cutting_programs/ wid/activities/womens_economicgrowth_rc htm economic, social, and political lives of their nations, communities, families and the next generations make them key actors in effective development. More than 800 million women are economically active worldwide -- in agriculture, small and micro enterprise, and, increasingly, in the export processing industries that drive globalization (Natsios, 2004). There is hardly any society in which women enjoy the same opportunities as men (FOS, 1997).

\section{Gender Inequality}

There are differences between women and men that are biological and social. Sex refers to the biological differences that are universal and unchanging. Gender refers to the social differences that are learned, changeable over time, and have wide variations within and between cultures. Gender is a socio-economic variable to analyze roles, responsibilities, constraints and opportunities of the people involved: it considers both women and men. Gender roles are learned behaviours in a given society; conditioning which activities, tasks and responsibilities are considered feminine and masculine. Gender roles are affected by age, class religion, ethnicity, regional origin and history. They can change because of several reasons, of which economic crisis is an important reason. They can also change because of fertility decline, increasing educational levels, introduction of new technology or development efforts. The gender roles of men and women are closely interrelated and may be similar, different, complementary or conflicting (Schoemaker, 1996). Women and men's responsibilities differ according to the specific situations in which they live; environment, economic conditions, occupations, class, culture and history, legal structures and religion shaped these circumstances (Thomas-Slayer, 1993).

\section{Gender differences in agricultural productivity}

The role of rural women in agriculture and in rural development has received increased attention in recent decades. This is exemplified in their contributions to food production and family earnings vis-á-vis skilled labour and entrepreneurship; and through female work groups rather than as family members (Udry et al., 1995; Kandiyoti, 1990). A number of studies addressed the specialized roles of women in terms of marketing of crops and products made from crops (Kanbur \& Haddad, 1994; Jones, 1986). Also, women provide a significant share of the labour (both family and hired) for farm activities and are important as primary producers of food crops (FAO, 1985; Weekes-Vagliani, 1985).

Studies have shown that women also play major roles in farm-level decision making, either as farm managers managing their own fields (Moock, 1976) or as 'effective decision makers' even in households in which the household head is a male, either because of their specific skills or when 
the husbands are absent for longer periods because they are employed in urban areas (Quisumbing, 1994). Several studies have addressed the question of differential farm productivity on plots managed by women and men (Udry et al., 1995; Ramaswamy, 1991; Saito, Mekonnen \& Spurling, 1994; Quisumbing, 1994). Haddad, Hoddinot and Alderman (1994) have utilized 'household' models in examining the role of women in agriculture and concluded that the participation of women in farm production and in labour markets varies greatly across societies and is clearly affected by culture and religion.

Nigerian women represent about 50.0 percent of the agricultural labour force and produce much of the country's food; farmwomen undertake most farm operations themselves; and rural women spent between 15-20 work hours on the average per day on agricultural and household subsistence work while men spent fifteen (Adebogun, 1994). If this is reflected in the production of cash crop like cocoa, this would have improved the economic status of women considerably well, which in turn would affect Nigeria's economic development.

Unfortunately, instead of gaining ownership and/or control over factors of production and productive assets, women face more constraints than men. Such constraints facing women, according to Adedoyin (1999) are: limited access to farmland; much of their time and labour controlled by their husbands and by their compound elders; difficulties in obtaining credit from institutional sources, which aggravate their limited ability to earn and control income of their own; and limited ability of women to own capital assets.

Women perform most of rural commodity transport work involving most commonly carrying of water, fuel, wood, harvested farm produce and goods to or from market. Other farm activities of women include crop production, livestock production, fishing and fish farming, forest resources management, agricultural products technology, storage and utilization, agro-processing, agricultural business management, community and rural development activities (through Co-operative, self-help, employment generation, education, health, social development programmes) (Adedoyin, 1999).

\section{Women's access to credit}

Rural women are constrained by lack of collateral as well as knowledge about any existing credit schemes. A study of such schemes in Kenya, Malawi, Sierra Leone, Zambia and Zimbabwe in 1990 revealed that women only took 10 percent of credit earmarked for small holders and only one percent of total credit to agriculture (FAO, 1997).

A lot of non-governmental organizations (NGOs) have also sprung up in the last few years providing micro-credit services to supplement the traditional methods of operating informal borrowing/ lending schemes. Unfortunately, these efforts are still scattered and have not reached desirable levels nor been effective in improving women's access to credit. Even where efforts are made to extend facilities to rural women, other factors such as intimidating procedures and inadequate information present formidable obstacles.
For example, the Family Economic Advancement Programme (FEAP) in Nigeria, which was planned to provide credit services and support services to strengthen income generation capacity, was abandoned by most women groups due to the long procedures which are rather cumbersome. The requirement for the loan did not consider the profile of rural populace who are mainly illiterates.

It is also well known that the improvement of living standards and general economic development in many areas of the world are characterized by a shift from subsistence agriculture to the cultivation of cash crops. Cocoa (theobroma cacao) is one of the most important commodities traded internationally and it is a crop that plays a strategic role in the economies of many developing countries. Olatunbosun and Olayide (1972) showed statistically that cocoa exports have been and will continue to be a significant factor in the economic growth of Nigeria. The contribution of cocoa among all agricultural exports from Nigeria showed that, the percentage of cocoa in the value of exports had been fluctuating but in a decreasing trend over the years. Two decades later, this position was reaffirmed as indicated by the Central Bank report. Between 1985 and 1993 cocoa commanded about 70 percent of the value of agricultural export (CBN, 1995).

However, cocoa, as economically significant as it may be, for instance, being a major raw material for many beverage industries, home and abroad, is facing the problem of acute neglect. This has resulted in a consistent decline in production in most of the world's cocoa producing countries including Nigeria. This may not be unconnected with the global economic recession, which consequently often precipitated price stagnation of this valued commodity (Kolawole, 2000). Many people have sensed that the oil wealth could not last forever and hence there is a dire need for a re-emphasis in favour of rebuilding Nigeria's export structure. Successive governments in Nigeria have failed to respond adequately to this challenge.

\section{Statement of the problem}

Agricultural tasks are partly or wholly gender specific. In a given culture, they are defined as appropriate to one or the other sex. However, because societies are constantly evolving and adapting to new pressures, the allocation of tasks between sexes within a community also undergoes change. For instance, some people are of the opinion that, in some cases, work that has traditionally been done by women is taken over by men once it has been mechanized (Akanji, 2002).

The cocoa economy of Nigeria has attracted a lot of writers because of its unique achievements for peasant agriculture. Numerous journals, articles, theses and books have highlighted these achievements and problems as well as solutions to them, (Adedayo, 1995; Awoyele, 1997; Aloba, 1999; Owofemi, 1999; Oyinloye, 1999). However, there are some unsettled questions, which need to be examined as further contributions to tentative solutions to some problems. One of the foremost questions concerns the gender factor in the structure and conduct in the industry and how this can be improved for increased benefits to all 
sectors of the cocoa economy. As the level of cocoa production and marketing in Nigeria keeps falling below expectation (Kolawole, 2000:11), this study examined the gender factor in all sides of the structure and conduct in the cocoa industry in Ondo State. In a bid to do this, the following critical questions were addressed:

- Is there gender segregation that serves as barrier to entry into cocoa business?

- What can be done to remove these barriers if any?

- Is there any difference between male and female cocoa marketers in terms of sales volume and access to critical resources such as capital, and labour and entrepreneurial capabilities?

- What are the key success and failure factors by gender?

The answers to these questions provided insight into the gender factor in the structure and conduct of Cocoa in Ondo State.

\section{Objectives of the study}

The general objective of this study is to examine the gender factor in the structure and conduct of cocoa industry in Ondo State with special reference to Idanre. The specific objectives of the study are to:

(a) examine gender differentiation of tasks and responsibilities in cocoa marketing.

(b) evaluate the level of success and failure among men and women in the structure of cocoa industry.

(c) Identify contributing factors to the level of success and failure among men and women in the structure and conduct of cocoa marketing activities and proffer solutions.

\section{Methodology}

\section{The selection of the firms}

The primary data for the study were obtained from Idanre town and villages of Ondo State, Nigeria between April 2000 and April 2001 by means of pre-tested questionnaires drawn in English and Yoruba languages.

\section{Justification for the selection of the firms in the area}

This area (henceforth called Idanre) has the largest volume of cocoa marketed from Ondo state yearly. As at Year 2000, 38.26 percent of the state's total cocoa output came from Idanre, while 16.25 percent of the country's total cocoa production came from Ondo State out of 36 states of the federation (OSMARD, 2001).

\section{Population and sample}

The study population was categorized into three, depending on the method used in sourcing the marketed cocoa beans.
Category A: Marketers who bought their marketed beans only. In this category 273 in all with 82 marketers drawn from the group.

Category B: Marketers who planted their marketed beans only. In this category, of the thirty-four marketers, only ten were drawn.

Category C: Marketers who got their beans by planting some and complementing those planted by other purchases. There were one hundred and ninety four marketers in this category; fifty-eight marketers were drawn from this category.

\section{Stratified random sampling technique}

The research focused on cocoa marketers from the farm to the last set of marketers who transport the collected beans out of Idanre. The marketers were randomly selected from registered marketers so obtained and a list of unregistered marketers, obtained from interactions with marketers in 'Alade', a market in Idanre, using the following variables with a sampling fraction of 30 percent:

a) Political/ Administrative zones: the marketers were divided into three existing political/administrative zones in the area based on their addresses.

b) Gender classification: Marketers were divided into two parts depending on whether they are male or female. A sampling fraction of 30 percent, reflective of the gender distribution in the parent population, was utilized: ninety-three out of three hundred and eleven male marketers and fifty seven out of one hundred and ninety female marketers were drawn which made the sample size to be 150 out of a population of 501 .

Out of the 150 questionnaires given out, 138 questionnaires were retrieved. The numbers in each class were randomly chosen. The data presented in this study were based on the 138 completed questionnaires received out of which 85 were males while 53 were females, with a mean age of 45 years. This stratified random sampling procedure helped to increase the statistical precision and reduce standard error, which are desirable rules of field experimentation.

\section{Techniques of data collection}

The primary data collection involved the use of structured and unstructured pre-tested sets of questionnaires, personal interviews, focus group discussions and direct observations. The questionnaires drawn in English and Yoruba solicited information from different institutions in the marketing channels. Additional data were also collected from secondary sources such as files available at the Ondo State Ministry of Agriculture and Rural Development, Akure and Produce Office, Idanre.

\section{Procedure for data analysis}

The data gathered were used to estimate the total expenses incurred by each cocoa marketer in marketing 1 tonne of dry cocoa beans. Other estimations included the gross revenue 
from cocoa, which was obtained by multiplying volume sold (in tonnes) by the actual producer price, which varied, from one seller to the other. The difference between the total revenue and the total amount spent, (excluding management cost) was the returns to management or profit (as used in this research work) for that period. All the above calculations were done for each cocoa marketer. The sales for female cocoa marketers were statistically compared with those of their male counterparts using the $\mathrm{t}-$ test.

The various cost elements in the study were identified as wages, transportation, labour, equipment, association fee, grading fee, and other miscellaneous items. They are called cost tracing variables. Lack of adequate record keeping by the marketers affected the collection of accurate data on these. The only items of cost for which adequate records were available for some of the marketers were wages, transportation, association fee, and grading fee. The others were based on the respondents' recall. That was why the marketers were asked for the total amount spent in marketing their products (that is Total Marketing Cost) to take care of some inadequacies in record keeping of some cost tracing variables.

From this exercise each firm's unit marketing cost (UMC) was estimated, which was calculated by dividing the total marketing cost by the volume of output handled. The Unit Marketing Margin (UMM) for each firm was obtained by subtracting the selling price of the commodity from its purchasing price. Multiplying this value by the quantity marketed resulted in the Total Marketing Margin. The total profit for each firm was determined by subtracting the Total Marketing Cost (TMC) from the Total Marketing Margin (TMM).

\section{Measures of market structure}

Structural indicators calculated for males, females and the industry were: Concentration Ratio (CR) - $\mathrm{CR}_{4}$, Herfindahl Index (HI) and Gini Coefficient.

The concentration ratio of an industry is used as an indicator of the relative size of firms in relation to the industry as a whole. The concentration ratio used in this study is the four-firm concentration ratio, which consists of the market share, as a percentage, of the four largest firms in the industry (QuickMBA, 2004).

The Herfindahl index is a measure of the size of firms in relationship to the industry and an indicator of the amount of competition among them. It is defined as the sum of the squares of the market shares of each individual firm in the industry (QuickMBA, 2004).

The Gini coefficient is a measure of income inequality developed by the Italian statistician Corrado Gini. The Gini coefficient is a number between 0 and 1 , where 0 corresponds with perfect equality (where everyone has the same income) and 1 corresponds with perfect inequality (where one person has all the income, and everyone else has zero income). To compute the Gini Coefficient, the area between the Lorenz Curve and the 45-degree equality line was first measured; the entire area below the 45-degree line (which is always exactly one half) was used to divide this measured area. The quotient is the Gini coefficient, a measure of inequality (Wikipedia, 2004).

\section{Measure of conduct}

Pricing is the only aspect of conduct used for this study.

Data analyses and other processes involved the use of both descriptive and inferential statistics using the computer Statistical Package for Social Sciences (SPSS).

\section{Results and discussion}

\section{Cocoa marketers and age}

The age of marketers ranged from 24 to 67 with an arithmetic mean of 45 in the pooled Idanre sample. The mean age for males and females were not statistically significantly different at the 10 percent level; and the modal ages for males, females and pooled samples were 43, 39 and 43 years respectively (Table 1 ).

Table 1: Age distribution and statistics of cocoa marketers by gender, Idanre sample: Ondo State of Nigeria, 2000/2001 season

\begin{tabular}{|c|c|c|c|c|}
\hline Age (years) & Male & Female & Total & $\%$ of Total \\
\hline Under 26 & 0 & 3 & 3 & 2,17 \\
\hline $26-35$ & 9 & 11 & 20 & 14,49 \\
\hline $36-45$ & 35 & 24 & 59 & 42,75 \\
\hline $46-55$ & 20 & 9 & 29 & 21,01 \\
\hline 56 and above & 19 & 6 & 25 & 18,12 \\
\hline No response & 2 & - & 02 & 1,45 \\
\hline Total & 85 & 53 & 138 & 100,00 \\
\hline \multicolumn{5}{|l|}{ Statistics: } \\
\hline Minimum Age & 28 & 24 & 24 & \\
\hline Maximum Age & 67 & 63 & 67 & \\
\hline Arith. mean Age & 47,19 & 42,49 & 45,35 & \\
\hline Median Age & 45 & 42 & 43,5 & \\
\hline Modal Age & $43 *$ & $39 *$ & 43 & \\
\hline
\end{tabular}

*Multiple modal ages: The smallest is shown.

Source: Akinola, 2003 
The study revealed that some 40 percent of marketers in the pooled sample were above 45 years; meaning that by the time the marketers grow too old for the business, the younger ones, constituting 60 percent of the sample would have become matured and can replace them. There is therefore no sign of shortage of cocoa marketers warranted by old age in the future.

\section{Years in business as cocoa marketers}

Table 2 summarizes findings on the number of years in business by the respondents, which revealed that there are wide variations in business experience by gender and location. The overall arithmetic mean number of years in cocoa marketing was 17 years. The findings further showed that male marketers are more experienced than female marketers and that all the marketers having more than 40 years of cocoa marketing experience were from Odoode.

About 41 percent of the marketers entered the industry within the last ten years (Table 2) but about 30 percent of them entered between 1980 and 1990. This could suggest that there had been a consistent increase in the net percentage of marketers entering the industry within the last sixty years. This phenomenon could also suggest that the real profit of cocoa marketing business over time had been relatively favourable, compared with other crops. However, for such an inference to be totally valid, one would need a measurement of exits (by reason) from the cocoa marketing industry as well as the features of these elements with respect to other crops in the area.

\section{Gender distribution in study's sample marketers}

Cocoa marketers in the study area were mostly men (62\%: Table 3). The highest percentage of respondents recorded in Atoshin were males (86\%); and the least, $51 \%$ of respondents existing in Alade were males (Table 3). The reasons for this, according to the respondents include the following:

- $\quad$ Cocoa business is tedious and risky; men have greater capacity to endure and bear the risks than women. Besides, men are physically stronger and possess the ability to stay away from home, which is one of the conditions for success in cocoa business. Men are more mobile and have better access to loans because of collateral securities that are to their advantage.

- Men dominate grading activity because they are more experienced in it. Grading is labour intensive and energy consuming and men are more energetic. This places men in an advantageous position in terms of buying and storing in large quantities and in exporting.

- Men dominate the spraying of cocoa in stores with chemicals because of their financial ability to purchase spraying equipment and bear the hazardous effects of the chemicals.

- $\quad$ Men have greater potential to bear risks when it comes to advancing and sourcing for money.
- Men also dominate in the collection and gathering of cocoa from farmers because of their physical strength to bear the hardship involved in those activities.

- The few marketers that are females (38\% of the marketers) dominate in:

i. pan buying commonly referred to as 'see and buy'. This is buying in bits and it is less cumbersome. However, it brings higher returns on invested capital. It does not require heavy capital and serious loans, nor large storage and it enhances good human relations in the community.

ii. There are more women in secretarial aspects of cocoa marketing because women are more meticulous than men.

\section{Business volume by gender and location}

Table 4 illustrates the marketers' distribution of Naira business volume by location and gender. There was no female marketer in Alade and Atoshin whose sales volume in the year 2001 exceeded eight hundred and four thousand Naira (N804, 000.00). In Odoode however, the maximum sales volume among females was some N6.2million, which in itself was lower than the overall arithmetic mean sales volume (N10.12million); and males overall arithmetic mean of N16.12million.

Females' overall arithmetic mean sales volume being N491, 812 conveys that male marketers were much better in terms of sales volume. The arithmetic mean value for men was 33 times the sales volume of female marketers. Moreover, the arithmetic mean sales volume was highest in Odoode (N25.7 million) followed by Atoshin (N3.9 million), trailed by Alade (N2.2 million). There were definitely statistically significant differences in the arithmetic mean sales volume by location and by gender for Alade and Odoode; but there was no statistically significant difference in the arithmetic mean sales volume by location and by gender for Atoshin at the ten percent level of significance.

\section{Volume of cocoa marketed per year}

Table 5 summarizes the findings on the volume of dried Cocoa beans marketed during the 2000/2001 season. It was found that only 17 percent of the marketers marketed over 100 metric tonnes of Cocoa beans during the season and they were all males.

The minimum volume marketed (0,5 MT) was handled by each of three females located at Alade and the maximum volume marketed (1000 MT) was handled by each of three male marketers in Odoode. The pooled sample mean of the volume of Cocoa marketed in the industry was $91 \mathrm{MT}$; the mean volume of cocoa marketed among males (145 MT) was statistically significantly higher than those of females (4 $\mathrm{MT}$ ) at the 10 percent level; that is, male cocoa marketers performed better in terms of total quantity marketed than their female counterparts. 
Table 2: Distribution and statistic of respondents' year in business as cocoa marketers by gender and location Ondo State of Nigeria 2000/2001season.

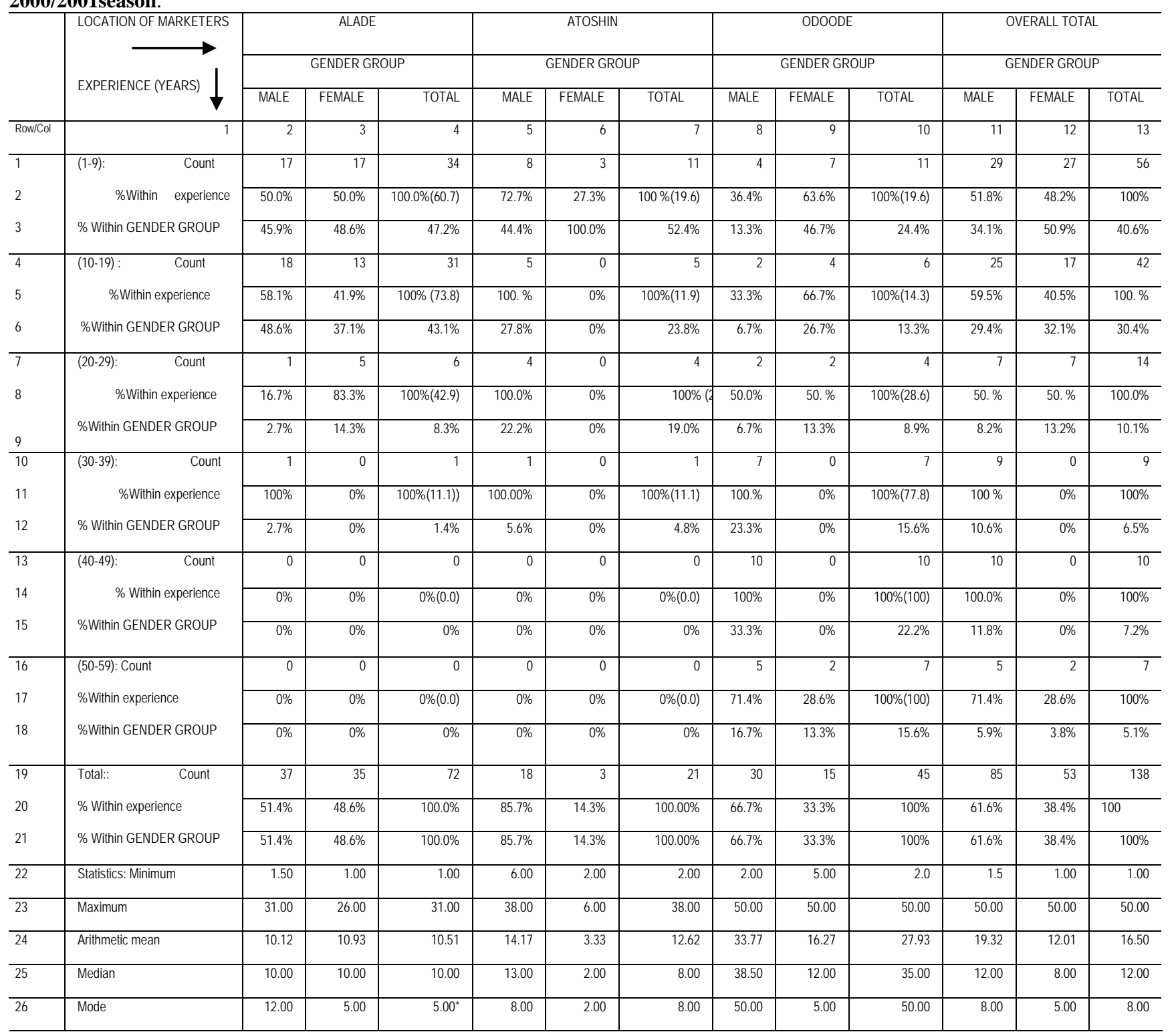

*Multiple modes exist. The smallest value is shown. The values in parentheses are the count of each total expressed as a percentage of overall total.

Source: Akinola, 2003

Table 3: Respondent marketers by gender and location, Idanre, Ondo State, Nigeria: 2000/2001 season

\begin{tabular}{|c|c|c|c|c|}
\hline & \multirow[t]{2}{*}{ LOCATION } & \multicolumn{2}{|c|}{ GENDER GROUP } & \multirow[t]{2}{*}{ TOTAI } \\
\hline & & Male & Female & \\
\hline Row/ Col & 1 & 2 & 3 & 4 \\
\hline 1 & Alade: Count & 37 & 35 & 72 \\
\hline 2 & No of Respondents to No in sample (\%) & 97,4 & 97,22 & 97,3 \\
\hline 3 & \%Within location & 51,4 & 48,8 & 100,0 \\
\hline 4 & \%Within Gender in sample space & 43,5 & 66,0 & 52,2 \\
\hline 5 & \% of Total in Sample space & 26,8 & 25,4 & 52,2 \\
\hline 6 & Atoshin: Count & 18 & 3 & 21 \\
\hline 7 & No of Respondents to No in sample (\%) & 75,0 & 50,0 & 70,0 \\
\hline 8 & \% Within LOCATION & 85,7 & 14,3 & 100,0 \\
\hline 9 & \% Within GENDER in sample space & 21,2 & 5,7 & 15,2 \\
\hline 10 & \% of Total in Sample space & 13,0 & 2,2 & 15,2 \\
\hline 11 & Odoode : Count & 30 & 15 & 45 \\
\hline 12 & No of Respondents to No in sample (\%) & 96,8 & 100,0 & 97,8 \\
\hline 13 & \%Within LOCATION & 66,7 & 33,3 & 100,0 \\
\hline 14 & \%Within GENDER in sample space & 35,3 & 28,3 & 32,6 \\
\hline 15 & $\%$ of Total in sample space & 21,7 & 10,9 & 32,6 \\
\hline 16 & Total: Count & 85 & 53 & 138 \\
\hline 17 & No of Respondents to No in sample (\%) & 91,4 & 93,0 & 92,0 \\
\hline 18 & \%Within LOCATION & 61,6 & 38,4 & 100,0 \\
\hline 19 & \%Within GENDER in sample space & 100,00 & 100,0 & 100,0 \\
\hline 20 & $\%$ of Total in sample space & 61,6 & 38,4 & 100,0 \\
\hline
\end{tabular}


Table 4: Statistics of volume of business (N) by location and gender: Cocoa marketers in Idanre , Ondo State Nigeria. 2000/2001

\begin{tabular}{|c|c|c|c|c|c|c|c|c|c|c|c|c|}
\hline \multicolumn{13}{|c|}{ LOCATION OF MARKETERS AND VOLUME OF BUSINESS (N) } \\
\hline & \multicolumn{3}{|c|}{ ALADE } & \multicolumn{3}{|c|}{ ATOSHIN } & \multicolumn{3}{|c|}{ ODOODE } & \multicolumn{3}{|c|}{ OVERALL } \\
\hline Statistics & Male & Female & Total & Male & Female & Total & Male & Female & Total & Male & Female & Total \\
\hline Minimum (N) & 103,500 & 55,775 & 55,775 & 112,000 & 105,000 & 105,000 & 157,500 & 76,400 & 76,400 & 103,500 & 55,775 & 55,775 \\
\hline Maximum(N) & $17,400,000$ & 804,000 & $17,400,000$ & $12,288,000$ & 120,000 & $12,288,000$ & $118,500,000$ & $6,162,000$ & $118,500,000$ & $118,500,000$ & $6,162,000$ & $118,500,000$ \\
\hline Mean (N) & $4,017,492$ & 313,802 & $2,217,087$ & $4,541,393$ & 114,333 & $3,908,956$ & $38,000,748$ & 982,666 & $25,661,388$ & $16,122,526$ & 491,812 & $10,119,426$ \\
\hline S D (N) & $5,049,368$ & 252,550 & $4,053,756$ & $4,935,114$ & 8,1445 & 4818,911 & $40,619,618$ & $2,074,541$ & $37,420,304$ & $29,149,886$ & $1,139,925$ & $24,077,040$ \\
\hline Median (N) & $1,960,000$ & 194,650 & 580,000 & $2,334,465$ & 118,000 & 352,500 & $11,791,250$ & 170,000 & $7,700,000$ & $4,800,000$ & 170,000 & 729,625 \\
\hline Mode (N) & $* 180,000$ & 120,000 & 120,000 & 300,000 & 000 & 300,000 & 000 & 240,000 & 240,000 & $* 180,000$ & 120,000 & 240,000 \\
\hline
\end{tabular}

When all males in the three locations were considered, there was no statistical significant difference in the means of males' quantity marketed in Alade (39 MT) and Atoshin (43 MT), while the means of males' quantity marketed in Odoode (338 MT) was statistically significantly higher than those of the other two locations at the ten percent level. Also, the performance of all females in the three locations was compared: Alade (3 MT average), Atoshin (1 MT average) and Odoode (8 MT average). It was found that there was no statistically significant difference in the mean quantity of cocoa marketed by female marketers in the three locations.

It was also found that the arithmetic mean quantity of cocoa marketed by male marketers was statistically significantly higher than those of female marketers in Alade and Odoode but there was no statistical significant difference in the arithmetic mean quantity marketed between male and female marketers in Atoshin.

\section{Structural indicators}

Table 6 summarizes the estimates of the concentration indicators. The figures obtained from the indicators show varying degrees of concentration by gender and location, with Odoode exhibiting the highest concentration of females (88.89\%, $\mathrm{CR}_{4}$ ) and Atoshin exhibiting the highest concentration $\left(56.48 \%, \mathrm{CR}_{4}\right)$ of males, and as well as in the pooled sample. The implication of these estimates is that where the concentration indices are high (belonging to as much as $50-74 \%, \mathrm{CR}_{4}$ ), there is a tendency for such a structure to influence some elements of performance especially profitability and operational efficiency (to the industry's advantage), if benefits are not shared between marketers and ultimate (at production farm end) purchasers.

Though the concentration was found not to be even, there was not too much difference in the degree of concentration by location and gender (see Figures 1, 2, 3 and 4). This suggests that, if there are any inter-location and inter-gender differences in performance, it is not due to the structure. The structure indicators obtained in this case are not such that it could lead to some conduct that would affect performance.

\section{Barriers to entry of new firms}

In this research work, investigation revealed that the structure of the industry did not seem to have contributed to the observed barriers to entry features. The major problems preventing new entrants into the industry within the past few years included transportation, instability of Cocoa prices (unforeseen fall in Cocoa prices), poor access to loan facilities and high bank interest rates on loans.

\section{Manner of sourcing the cocoa beans marketed.}

The seventh table summaries how the cocoa beans marketed were sourced. The table conveys that the majority of the marketers (54\%) obtained their marketed cocoa beans by buying only from either farmers, brokers or local buying agents. With respect to female marketers about $77 \%$ of them obtained their marketed cocoa beans from this type of source. About $52 \%$ of male marketers got their beans by planting some and complementing that by other purchases.

\section{Sources of capital}

Table 8 summarizes the findings on the sources of capital used by marketers in carrying out their business operations. The study revealed that about 53 percent of the marketers benefited from one form of loan or the other during the 2000/2001 season. The largest percentage of these loan beneficiaries (63\%) obtained some of their loans from Banks (commercial and / or agricultural) and (52\%) of them obtained loans from cooperative societies.

The majority (about 82\%) of those that obtained some money from licensed buying agents were males. Male marketers also dominate among those who obtained their capital through loans from friends and relations (57\%), Agricultural Development Corporations (ADCs) (100\%), and exporters (80\%). It is only in loans from cooperative societies that female marketers have the majority (58\%). No female marketer had access to loans from ADCs.

It can be concluded here that the majority of cocoa marketers (67.4\%) relied too much on capital from savings and loans from friends and relations. This appears rather inadequate and unreliable to generate enough capital to run their business successfully; more so that little capital has been identified as one of the major causes of business failure in the industry. 
Table 5: Distribution of statistics of volume of cocoa marketed by gender and location: Ondo State of Nigeria, 2000/2001 Season

\begin{tabular}{|c|c|c|c|c|c|c|c|c|c|c|c|c|c|}
\hline & \multirow{3}{*}{$\begin{array}{l}\text { LOCATION OF MARKETERS } \\
\text { VOLUME OF COCOA MARKETED } \\
\text { (TONNES) }\end{array}$} & \multicolumn{3}{|c|}{ ALADE } & \multicolumn{3}{|c|}{ ATOSHIN } & \multicolumn{3}{|c|}{ ODOODE } & \multicolumn{3}{|c|}{ OVERALL TOTAL } \\
\hline & & & ENDER GR & & & ENDER GR & & & ENDER G & & & NDER GRC & \\
\hline & & MALE & FEMALE & TOTAL & MALE & FEMALE & TOTAL & MALE & FEMALE & TOTAL & MALE & FEMALE & TOTAL \\
\hline Row/ Col & 1 & 2 & 3 & 4 & 5 & 6 & 7 & 8 & 9 & 10 & 11 & 12 & 13 \\
\hline 1 & (0.5-1): & 2 & 15 & 17 & 3 & 3 & 6 & 0 & 6 & 6 & 5 & 24 & 29 \\
\hline 2 & $\%$ within Total Quantity Marketed & $11,3 \%$ & 88,2 & $100 \%(58,6)$ & $50 \%$ & $50 \%$ & $100 \%(20,7)$ & $0 \%$ & $100 \%$ & $100(20,7)$ & $17,2 \%$ & $82,8 \%$ & $100 \%$ \\
\hline 3 & \% Within GENDER GROUP & $5,4 \%$ & $42,9 \%$ & $23,6 \%$ & $16,7 \%$ & $100 \%$ & 28,6 & $0 \%$ & $40 \%$ & $13,3 \%$ & 5,9 & $45,3 \%$ & $21,0 \%$ \\
\hline 4 & $(2-4):$ & 7 & 11 & 18 & 6 & 0 & 6 & 3 & 6 & 9 & 16 & 17 & 33 \\
\hline 5 & \%Within Total Quantity Marketed & $38,9 \%$ & $61,1 \%$ & $100 \%(54,5)$ & $100, \%$ & $0,0 \%$ & $100 \%(18,2)$ & $33,3 \%$ & $66,7 \%$ & $100(27,3))$ & $48,5 \%$ & $51,5 \%$ & $100 \%$ \\
\hline 6 & \% Within GENDER GROUP & $18,9 \%$ & $31,4 \%$ & 25 & $33,3 \%$ & $0,0 \%$ & $28,6 \%$ & 10,0 & $40,0 \%$ & $20 \%$ & $18,8 \%$ & $32,1 \%$ & $23,9 \%$ \\
\hline 7 & $(5 .-20):$ & 13 & 9 & 22 & 0 & 0 & 0 & 0 & 1 & 1 & 13 & 10 & 23 \\
\hline 8 & \%Within Total Quantity Marketed & 59,1 & $40,9 \%$ & $100(95,7)$ & $0,0 \%$ & $0,0 \%$ & $0,0 \%$ & $0,0 \%$ & $100 \%$ & $100(4,3)$ & $66,5 \%$ & $43,5 \%$ & $100,0 \%$ \\
\hline 9 & \%with GENDER GROUP & 35,1 & 25,7 & 30,6 & $0,0 \%$ & $0,0 \%$ & $0,0 \%$ & $0,0 \%$ & $6,7 \%$ & $2,2 \%$ & $15,3 \%$ & $18,9 \%$ & $16,7 \%$ \\
\hline 10 & $(21-100): c$ & 9 & 0 & 9 & 7 & 0 & 7 & 12 & 2 & 14 & 28 & 2 & 30 \\
\hline 11 & \%within Total Quantity Marketed & $100 \%$ & $0,0 \%$ & $100(30)$ & $100 \%$ & $0,0 \%$ & $100(23,3)$ & $85,7 \%$ & $14,3 \%$ & $100(46,7)$ & $93,3 \%$ & $6,7 \%$ & $100 \%$ \\
\hline 12 & $\%$ within GENDER GROUP & 24,3 & $0,0 \%$ & $12,5 \%$ & $38,9 \%$ & $0,0 \%$ & 33,3 & $40,0 \%$ & $13,3 \%$ & $31,1 \%$ & $32,9 \%$ & $3,8 \%$ & $21,7 \%$ \\
\hline 13 & (101-500): & 6 & 0 & 6 & 2 & 0 & 2 & 9 & 0 & 9 & 17 & 0 & 17 \\
\hline 14 & $\%$ within Total Quantity Marketed & $100 \%$ & 0 & $100(35,3)$ & $100 \%$ & $0 \%$ & $100(11,8$ & $100 \%$ & $0,0 \%$ & $100(52,9)$ & $100 \%$ & $0,0 \%$ & $100 \%$ \\
\hline 15 & \%within GENDER GROUP & $16,2 \%$ & $0 \%$ & $8,3 \%$ & $11,1 \%$ & $0 \%$ & $9,5 \%$ & $30,3 \%$ & $0 \%$ & $20,0 \%$ & $20,0 \%$ & $0,0 \%$ & $12,3 \%$ \\
\hline 16 & (501-1000): & 0 & 0 & 0 & 0 & 0 & 0 & 6 & 0 & 6 & 6 & 0 & 6 \\
\hline 17 & \%within Total Quantity Marketed & $0,0 \%$ & $0,0 \%$ & $0,0 \%$ & $0,0 \%$ & $0,0 \%$ & $0,0 \%$ & $100 \%$ & $0 \%$ & $100(100)$ & $100 \%$ & $0,0 \%$ & $100 \%$ \\
\hline 18 & \%within GENDER GROUP & $0,0 \%$ & $0,0 \%$ & $0,0(0,0)$ & $0,0 \%$ & $0,0 \%$ & $0,0(0,0)$ & $20 \%$ & $0 \%$ & $13,3 \%$ & $7,1 \%$ & $0,0 \%$ & $4,3 \%$ \\
\hline 19 & Count & 37 & 35 & 72 & 18 & 3 & 21 & 30 & 15 & 45 & 85 & 53 & 138 \\
\hline 20 & $\%$ within Total Quantity Marketed & $51,4 \%$ & $48,6 \%$ & $100(52,2)$ & $85,7 \%$ & $14,3 \%$ & $100(15,2)$ & $66,7 \%$ & $33,3 \%$ & $100(32,6)$ & $61,6 \%$ & $38,4 \%$ & 100 \\
\hline 21 & $\%$ within GENDER GROUP & $100 \%$ & $100 \%$ & $100 \%$ & $100 \%$ & $100 \%$ & $100 \%$ & $100 \%$ & $33,3 \%$ & $100 \%$ & $100 \%$ & $38,4 \%$ & $100 \%$ \\
\hline 22 & Statistics: Smallest Vol. (Tonnes) & 0,90 & 0,50 & 0,50 & 1,00 & 1,00 & 1,00 & 1,70 & 0,80 & 0,80 & 0,80 & 0,50 & 0,50 \\
\hline 23 & Largest & 150 & 6,70 & 150 & 128,0 & 1,00 & 128,00 & 1000 & 52,00 & 1000 & 1000 & 52,00 & 1000 \\
\hline 24 & Arithmetic mean " & 38,5 & 3 & 21 & 43 & 1 & 37 & 338 & 8 & 228 & 145 & 4 & 91 \\
\hline 25 & Median & 18 & 2 & 5 & 23 & 1 & 3 & 107 & 2 & 70 & 46 & 2 & 6 \\
\hline 26 & Mode & 3 & 1 & 1 & 3 & 1 & 1 & 100 & 2 & 2 & 3 & 1 & 1 \\
\hline
\end{tabular}

Note: The values in parentheses are the count of each total expressed as a percentage of overall total.

Source: Akinola, 2003.

The female marketers attributed their inability to benefit from the various loans to their lack of their collateral security. Even some of those who had securities lamented that most of the awarders of these loans were afraid of giving out loans to women because they felt they may not be competent enough to manage them resourcefully. This implied the existence of gender discrimination against women in access to credit.

\section{Sources of cocoa beans for market}

Table 9 summarises the findings on the sources of marketed cocoa beans by gender. The study revealed that the majority of the cocoa marketers (91\%; out of which $63 \%$ were males) bought some or all of their cocoa beans from farmers. No female marketer obtained her cocoa beans either from land inherited or land hired on which a certain pledge is paid. This constituted $19 \%$ of those that obtained from land purchased. This could be linked with the problems identified by Berar-Awad (1989:6-11) in respect of women's access to land ownership. Women constitute about 70,5\% of those who used the 'See and buy' purchase method, the reasons for this feature being that the method does not require big capital coupled with the fact that women's acumen for bargaining power and measuring potential is higher than that of men.

\section{Methods of sourcing marketable cocoa beans}

The majority of all cocoa marketers (51 percent; $57 \%$ of which were females) sourced their cocoa beans by granting loans to farmers during the planting season and collecting dried cocoa beans in return (Table 10). The next prominent method of sourcing, utilized by 46,4 percent of the marketers, was through supplying farmers some inputs. The other methods as shown in Table 10 are the use of LBAs, the 'see and buy' method and the method of augmenting transportation of farmers' products. 


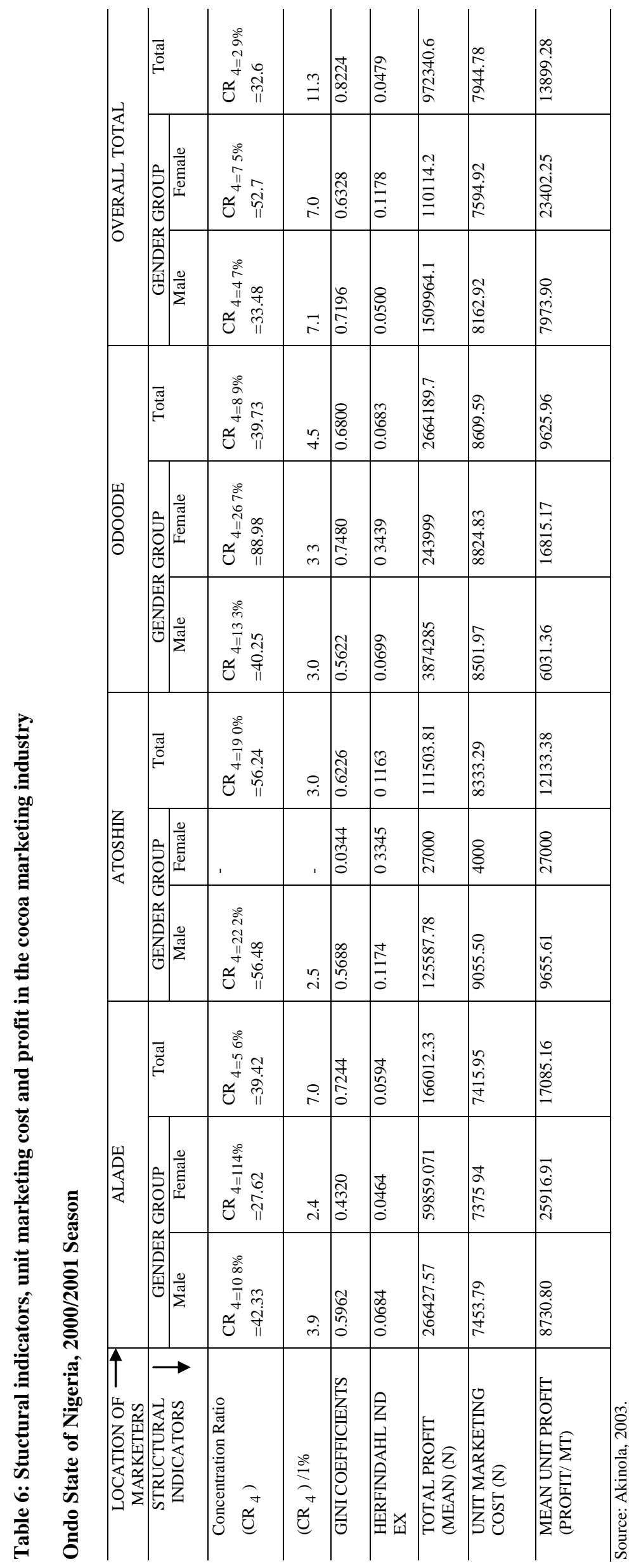


Table 7: Manner of sourcing Cocoa Beans marketed by gender, Ondo State of Nigeria, 2000/2001 season.

\begin{tabular}{|c|c|c|c|c|}
\hline & \multirow{2}{*}{ Manner of sourcing } & \multicolumn{3}{|c|}{ GENDER GROUP } \\
\hline & & Male & Female & Total \\
\hline Row/ Col & 1 & 2 & 3 & 4 \\
\hline 1 & Buy only: Number & 34 & 41 & 75 \\
\hline$\frac{1}{2}$ & \%Within manner of sourcing & 45,3 & 54,7 & 100,0 \\
\hline 3 & \%Within GENDER GROUP & 40,0 & 77,4 & 54,3 \\
\hline 4 & \% Within Total Respondents & 24,6 & 29,7 & 54,3 \\
\hline 5 & Plant only: Number & 07 & 02 & 09 \\
\hline 6 & \%Within manner of sourcing & 77,8 & 22,2 & 100,0 \\
\hline 7 & \%Within GENDER GROUP & 8,2 & 3,8 & 6,5 \\
\hline 8 & \% Within Total Respondents & 5,1 & 1,4 & 6,5 \\
\hline 9 & Plant and Buy only: Number & 44 & 10 & 54 \\
\hline 10 & \%Within manner of sourcing & 81,5 & 18,5 & 100,0 \\
\hline 11 & \%Within GENDER GROUP & 51,8 & 18,9 & 39,1 \\
\hline$\frac{11}{12}$ & \% Within Total Respondents & 31,9 & 7,2 & 39,1 \\
\hline 13 & Total: Number & 85 & 53 & 138 \\
\hline 14 & \%Within manner of sourcing & 61,6 & 38,4 & 100,0 \\
\hline 15 & \%Within GENDER GROUP & 100,0 & 100,0 & 100,0 \\
\hline$\frac{10}{16}$ & \% Within Total Respondents & 61,6 & 38,4 & 100,0 \\
\hline
\end{tabular}

Table 8: Sources of capital by gender: Cocoa marketers in Idanre, Ondo State; 2000/2001 Season

\begin{tabular}{|c|c|c|c|c|}
\hline & \multirow[b]{2}{*}{ SOURCE OF CAPITAL } & \multicolumn{3}{|c|}{ GENDER GROUP } \\
\hline & & Male & Female & Total \\
\hline Row/Col & 1 & 2 & 3 & 4 \\
\hline 1 & \multirow{4}{*}{$\begin{array}{l}\text { Personal Savings: Number } \\
\text { \%within CAPITAL SOURCE } \\
\text { \%within GENDER GROUP } \\
\text { \% within Total Respondents }\end{array}$} & 35 & 30 & 65 \\
\hline 2 & & 53,8 & 46,2 & 100,0 \\
\hline 3 & & 41,1 & 56,6 & 47,1 \\
\hline 4 & & 25,4 & 21,7 & 47,1 \\
\hline 5 & \multirow{4}{*}{$\begin{array}{l}\text { Loans from Friends and Relatives: Number } \\
\text { \%Within CAPITAL SOURCE } \\
\text { \%Within GENDER GROUP } \\
\text { \% Within Total Respondents }\end{array}$} & 16 & 12 & 28 \\
\hline 6 & & 57,1 & 42,9 & 100,0 \\
\hline 7 & & 18,8 & 22,6 & 20,3 \\
\hline 8 & & 11,6 & 8,7 & 20,3 \\
\hline 9 & \multirow{4}{*}{$\begin{array}{l}\text { Loans from Licensed Buying Agents: Number } \\
\text { \%Within CAPITAL SOURCE } \\
\text { \%Within GENDER GROUP } \\
\text { \% Within Total Respondents }\end{array}$} & 22 & 05 & 27 \\
\hline 10 & & 81,5 & 18,5 & 100,0 \\
\hline 11 & & 25,9 & 9,4 & 19,6 \\
\hline 12 & & 15,9 & 3,6 & 19,6 \\
\hline 13 & \multirow{4}{*}{$\begin{array}{l}\text { Loans from Banks (Commercial and/Agricultural: Number } \\
\text { \%Within CAPITAL SOURCE } \\
\text { \%Within GENDER GROUP } \\
\text { \% Within Total Respondents }\end{array}$} & 32 & 14 & 46 \\
\hline 14 & & 69,6 & 30,4 & 100,0 \\
\hline 15 & & 37,6 & 26,4 & 33,3 \\
\hline 16 & & 23,2 & 10,1 & 33,3 \\
\hline 17 & \multirow{4}{*}{$\begin{array}{l}\text { Loans from Cooperative Societies: Number } \\
\text { \%Within CAPITAL SOURCE } \\
\text { \%Within GENDER GROUP } \\
\text { \% Within Total Respondents }\end{array}$} & 16 & 22 & 38 \\
\hline 18 & & 42,1 & 57,9 & 100,0 \\
\hline 19 & & 18,8 & 41,5 & 27,5 \\
\hline 20 & & 11,6 & 15,9 & 27,5 \\
\hline 21 & \multirow{4}{*}{$\begin{array}{l}\text { Loans from Agric Development Corporations: Number } \\
\text { \%Within CAPITAL SOURCE } \\
\text { \%Within GENDER GROUP } \\
\text { \% Within Total Respondents }\end{array}$} & 02 & 0,0 & 02 \\
\hline 22 & & 100,0 & 0,0 & 100,0 \\
\hline 23 & & 2,4 & 0,0 & 1,4 \\
\hline 24 & & 1,4 & 0,0 & 1,4 \\
\hline 25 & \multirow{4}{*}{$\begin{array}{l}\text { Loans from Exporters: Number } \\
\text { \%Within CAPITAL SOURCE } \\
\text { \%Within GENDER GROUP } \\
\text { \% Within Total Respondents }\end{array}$} & 16 & 04 & 20 \\
\hline 26 & & 80 & 20 & 100,0 \\
\hline 27 & & 18,8 & 7,5 & 14,5 \\
\hline 28 & & 11,6 & 2,9 & 14,5 \\
\hline
\end{tabular}

Source: Akinola, 2003 
Table 9: Sources of marketed cocoa beans by marketers and by gender; Idanre, Ondo State of Nigeria. 2000/2001 Season.

\begin{tabular}{|c|c|c|c|c|c|}
\hline & \multirow{2}{*}{\multicolumn{2}{|c|}{ Source of cocoa beans }} & \multicolumn{2}{|c|}{ GENDER GROUP } & \multirow[b]{2}{*}{ Total } \\
\hline & & & Male & Female & \\
\hline Row/ Col & \multicolumn{2}{|c|}{1} & 2 & 3 & 4 \\
\hline 1 & \multirow{4}{*}{\multicolumn{2}{|c|}{$\begin{array}{l}\text { From land inherited: } \\
\text { \% Within COCOA SOURCE } \\
\text { \% Within GENDER GROUP } \\
\text { \% Within Total Respondents }\end{array}$}} & 24 & 00 & 24 \\
\hline 2 & & & 100,0 & 0,0 & 100.0 \\
\hline 3 & & & 28,2 & 0,0 & 17.4 \\
\hline 4 & & & 17,4 & 0,0 & 17.4 \\
\hline 5 & \multirow{4}{*}{$\begin{array}{l}\text { From land purchased: } \\
\text { \% Within COCOA SOURCE } \\
\text { \% Within GENDER GROUP } \\
\text { \% Within Total Respondents }\end{array}$} & \multirow[t]{4}{*}{ Number } & 35 & 08 & 43 \\
\hline 6 & & & 81,4 & 18,6 & 100.0 \\
\hline 7 & & & 41,2 & 15,1 & 31.2 \\
\hline 8 & & & 25,4 & 5,8 & 31.2 \\
\hline 9 & \multirow{4}{*}{\multicolumn{2}{|c|}{$\begin{array}{l}\text { From land hired on which certain pledge is paid: } \\
\text { \% Within COCOA SOURCE } \\
\text { \% Within GENDER GROUP } \\
\% \text { Within Total Respondents }\end{array}$}} & 05 & 00 & 05 \\
\hline 10 & & & 100,0 & 0,0 & 100.0 \\
\hline 11 & & & 5,9 & 0,0 & 3.6 \\
\hline 12 & & & 3,6 & 0,0 & 3.6 \\
\hline 13 & \multirow{4}{*}{$\begin{array}{l}\text { Bought from farmers: } \\
\text { \% Within COCOA SOURCE } \\
\text { \% Within GENDER GROUP } \\
\text { \% Within Total Respondents }\end{array}$} & \multirow[t]{4}{*}{ Number } & 79 & 45 & 125 \\
\hline 14 & & & 63,2 & 36,8 & 100.0 \\
\hline 15 & & & 92,9 & 86,8 & 90.6 \\
\hline 16 & & & 57,2 & 33,3 & 90.6 \\
\hline 17 & \multirow{4}{*}{\multicolumn{2}{|c|}{$\begin{array}{l}\text { From Brokers/ See and Buy: } \\
\text { \% Within COCOA SOURCE } \\
\text { \% Within GENDER GROUP } \\
\text { \% Within Total Respondents }\end{array}$}} & 14 & 31 & 45 \\
\hline 18 & & & 31,8 & 70,5 & 100.0 \\
\hline 19 & & & 16,5 & 66,0 & 32.6 \\
\hline 20 & & & 10,1 & 22,5 & 32.6 \\
\hline
\end{tabular}

Source: Akinola, 2003

\section{Conclusion and recommendations}

The study showed that there was no gender segregation that served as barriers to entry into cocoa business. Although female cocoa marketers performed better in terms of unit profit than their male counterparts and male marketers performed better in terms of sales volume and had more access to capital, there was gender discrimination against women in access to credit, which made their mean gross profit to be lower than their male counterparts. Based on the findings from this study, the following recommendations were made to improve the performance of the cocoa marketing industry in Ondo State:

(i) Female cocoa marketers in Ondo State possess tremendous ability to succeed in the business if only their opportunities to credit facilities and capital could be enhanced.

(ii) Marketers are advised to avail themselves of opportunity of loans from banks or Credit Cooperative Societies.

(iii) Awareness must be created for cocoa marketers on the available sources of funds to them both locally and internationally. In addition, relevant organizations should enunciate procedures for obtaining funds from these various sources.

(iv) Both formal and informal financial institutions in the country should be encouraged by the government to provide financial assistance to the cocoa marketers (most especially female marketers) so that they can expand and improve their existing business volume. (v) The Federal Government should set up a government parastatal called Cocoa Business Administration (CBA), to assist cocoa marketers through:

- $\quad$ Direct Loans - loans made directly to selected cocoa marketers who have difficulty securing conventional loans;

- Guaranteed Loans - loans made by financial institutions that the government will repay if the borrower stops making payments;

- $\quad$ Participation loans - Combination of direct and guaranteed loans. The CBA will guarantee part of the loan and will loan the balance directly; and

- Loans from the Women's Financing Section guaranteed loans to qualified women to be created by the Women's Cocoa Business Ownership Act, when formulated and passed.

(vi) If and when enough capital is subsequently generated for the cocoa business, it must be emphasized to marketers through a well-organised seminar, that poor financial management can destroy any business; even when the basic idea behind the business is good and the products are accepted in the marketplace.

(vii) There should be construction of good roads linking farms to cities by the government.

(viii) Government should subsidize the price of chemicals and ensure that the chemicals are distributed to the right people. 
(ix) In order to solve the problems of fraudsters, Government should enforce the laws on those found guilty and be brought to book.

(x) Marketers should closely monitor farmers to whom money had been advanced and they should request for guarantors or written agreement from whosoever they want to advance money to.

(xi) Male marketers should make more use of a "see and buy" method to prevent them from falling victim of fraudsters.

Table 10: Sources of marketed cocoa beans by marketers and by gender; Idanre, Ondo State of Nigeria. 2000/2001 Season.

\begin{tabular}{|c|c|c|c|c|c|}
\hline & \multirow{2}{*}{\multicolumn{2}{|c|}{ Method }} & \multicolumn{2}{|c|}{ GENDER GROUP } & \multirow[b]{2}{*}{ Total } \\
\hline & & & Male & Female & \\
\hline Row/ Col & \multicolumn{2}{|l|}{1} & 2 & 3 & 4 \\
\hline 1 & \multirow{4}{*}{$\begin{array}{l}\text { Buyers residing in the farm (LBAs): } \\
\text { \% Within Method } \\
\text { \% Within GENDER GROUP } \\
\text { \% Within Total Respondents }\end{array}$} & \multirow[t]{4}{*}{ Number: } & 43 & 04 & 47 \\
\hline 2 & & & 91,5 & 8,5 & 100,0 \\
\hline 3 & & & 50,6 & 7,5 & 34,1 \\
\hline 4 & & & 31,2 & 2,9 & 34,1 \\
\hline 5 & \multirow{4}{*}{$\begin{array}{l}\text { By supplying farmers some input: } \\
\text { \% Within Method } \\
\text { \% Within GENDER GROUP } \\
\text { \% Within Total Respondents }\end{array}$} & \multirow[t]{4}{*}{ Number: } & 24 & 40 & 64 \\
\hline 6 & & & 37,5 & 62,5 & 100,0 \\
\hline 7 & & & 28,2 & 75,5 & 46,4 \\
\hline 8 & & & 17,4 & 29,0 & 46,4 \\
\hline 9 & \multirow{4}{*}{\multicolumn{2}{|c|}{$\begin{array}{l}\text { By granting farmers loans during planting season and } \\
\text { collecting dried cocoa beans in return: } \\
\text { \% Within Method } \\
\text { \% Within GENDER GROUP } \\
\text { \% Within Total Respondents }\end{array}$}} & 30 & 40 & 70 \\
\hline 10 & & & 42,9 & 57,1 & 100,0 \\
\hline 11 & & & 35,3 & 75,5 & 50,7 \\
\hline 12 & & & 21,7 & 29,0 & 50,7 \\
\hline 13 & \multirow{4}{*}{$\begin{array}{l}\text { See and Buy: } \\
\text { \% Within Method } \\
\text { \% Within GENDER GROUP } \\
\text { \% Within Total Respondents }\end{array}$} & \multirow[t]{4}{*}{ Number: } & 12 & 31 & 43 \\
\hline 14 & & & 27,9 & 72,1 & 100,0 \\
\hline 15 & & & 14,1 & 58,5 & 31,2 \\
\hline 16 & & & 8,7 & 22,5 & 31,2 \\
\hline 17 & \multirow{4}{*}{$\begin{array}{l}\text { Augmenting transportation of producer's products: } \\
\text { \% Within Method } \\
\text { \% Within GENDER GROUP } \\
\text { \% Within Total Respondents }\end{array}$} & \multirow[t]{4}{*}{ Number: } & 10 & 00 & 10 \\
\hline 18 & & & 100,0 & 0,0 & 100,0 \\
\hline 19 & & & 11,8 & 0,0 & 7,2 \\
\hline 20 & & & 7,2 & 0,0 & 7,2 \\
\hline 21 & \multirow{4}{*}{$\begin{array}{l}\text { No Response: } \\
\text { \% Within Method } \\
\text { \% Within GENDER GROUP } \\
\text { \% Within Total Respondents }\end{array}$} & \multirow[t]{4}{*}{ Number: } & 05 & 00 & 05 \\
\hline 22 & & & 100,0 & 0,0 & 100,0 \\
\hline 23 & & & 5,9 & 0,0 & 3,6 \\
\hline 24 & & & 3,6 & 0,0 & 3,6 \\
\hline
\end{tabular}




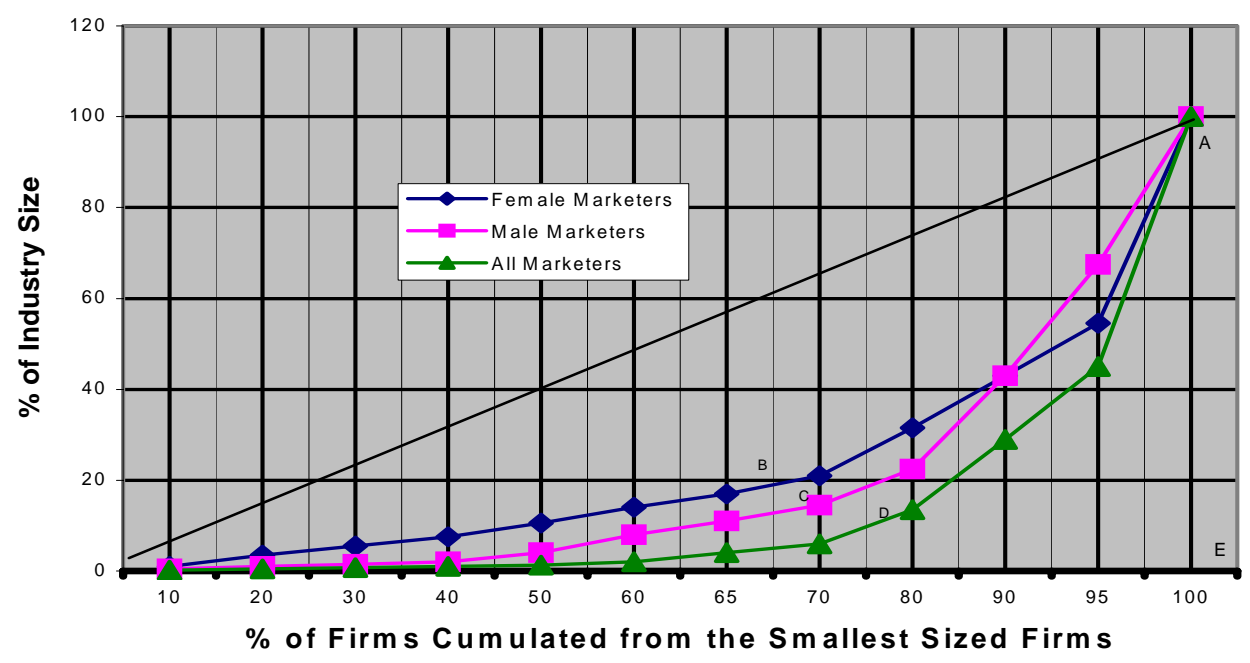

Figure 1: Lorenz curves for marketers in cocoa industry in Idanre, Ondo State, Nigeria. 2000/2001 Season Source: Akinola, 2003.

$\begin{aligned} \text { Gini Coefficient For: } \quad \text { Female Marketers } & =\frac{\mathrm{OAB}}{\mathrm{OAE}}=\frac{3164}{5000}=0,6328 \\ \text { Male Marketers } & =\frac{\mathrm{OAC}}{\mathrm{OAE}}=\frac{3598}{5000}=0,7196 \\ \text { All Marketers } & =\frac{\mathrm{OAD}}{\mathrm{OAE}}=\frac{4112}{5000}=0,8224\end{aligned}$

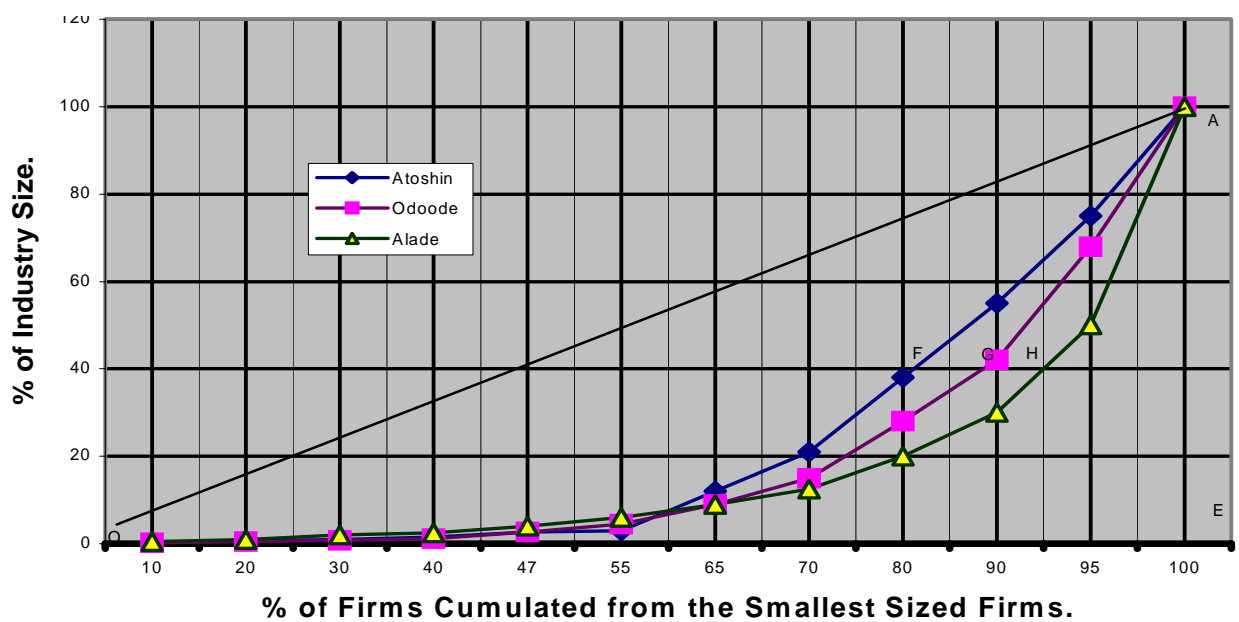

Figure 2: Lorenz curves for marketers in cocoa industry in Alade, Atoshin, and Odoode in Idanre, Ondo State, Nigeria. 2000/2001 Season

Source: Akinola, 2003.

Gini Coefficient For Marketers in: $\quad$ Alade $\quad=\frac{\mathrm{OAH}}{\mathrm{OAE}}=\frac{3622}{5000}=0,7244$

Atoshin $=\frac{\mathrm{OAF}}{\mathrm{OAE}}=\frac{3113}{5000}=0,6226$

Odoode $=\frac{\mathrm{OAG}}{\mathrm{OAE}}=\frac{3400}{5000}=0,6800$ 


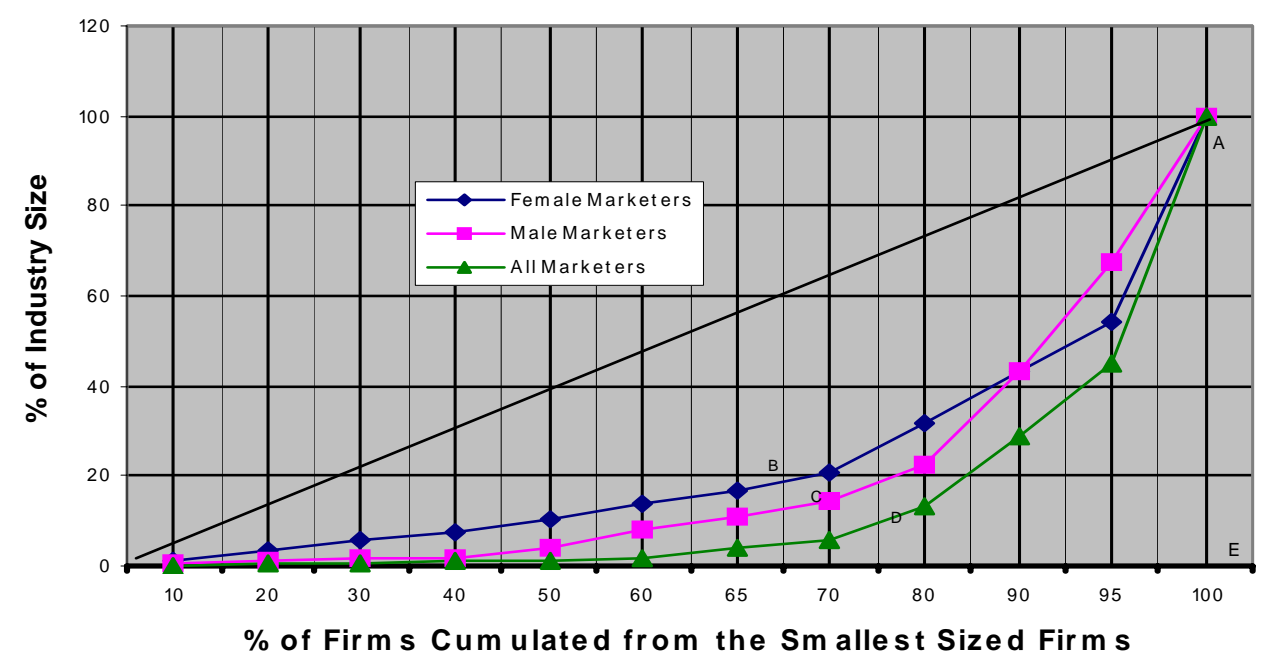

Figure 3: Lorenz curves for female marketers in cocoa industry in Alade, Atoshin, and Odoode in Idanre, Ondo State, Nigeria. 2000/2001 Season

Source: Akinola, 2003.

Gini Coefficient For Female Marketers in: Alade

$=\quad \frac{\mathrm{OAK}}{\mathrm{OAE}}=\frac{2160}{5000}=0,4320$

$\begin{array}{lll}\text { Atoshin } & = & \frac{\mathrm{OAJ}}{\mathrm{OAE}}=\frac{172}{5000}=0,0344 \\ \text { Odoode } & = & \frac{\mathrm{OAL}}{\mathrm{OAE}}=\frac{3740}{5000}=0,7480\end{array}$

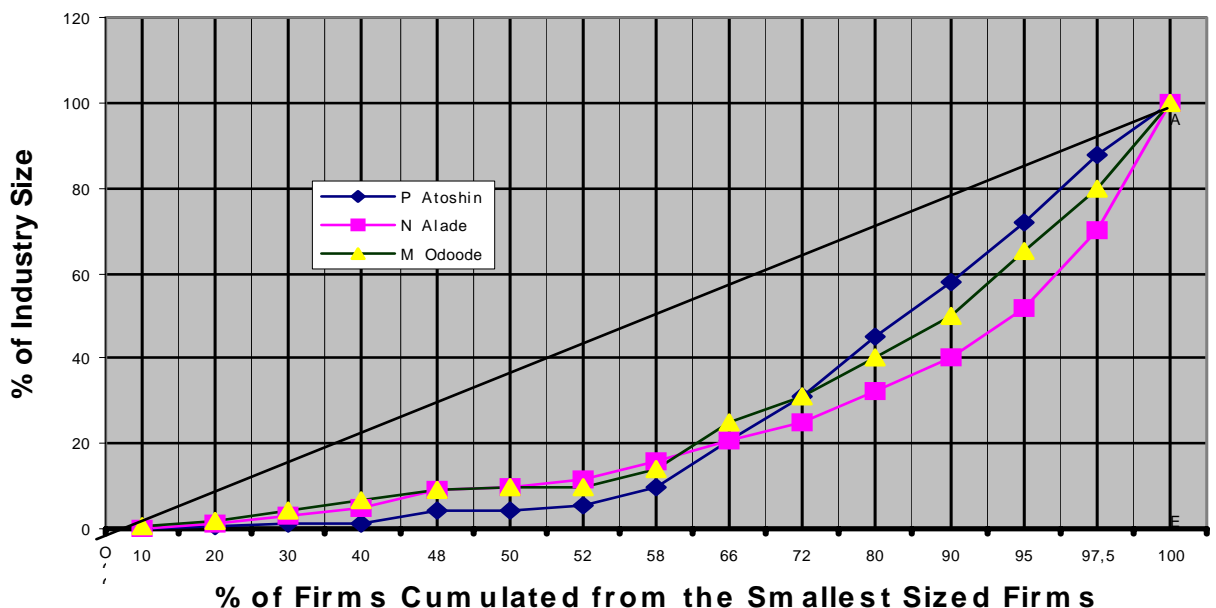

Figure 4: Lorenz curves for male marketers in cocoa industry in Alade, Atoshin, and Odoode in Idanre, Ondo State, Nigeria. 2000/2001 Season

Source: Akinola, 2003.

Gini Coefficient For Male Marketers in: Alade $=\frac{\mathrm{OAM}}{\mathrm{OAE}}=\frac{2981}{5000}=0,5962$

Atoshin $=\frac{\mathrm{OAP}}{\mathrm{OAE}}=\frac{2844}{5000}=0,5688$

Odoode $=\frac{\mathrm{OAN}}{\mathrm{OAE}}=\frac{2811}{5000}=0,5622$ 


\section{References}

Adebogun, A.A. 1994. 'A study of the effectiveness of linkages between agricultural extension and rural women in Ogun State Nigeria'. Unpublished B. Agric Project Report, Ogun State University, Ago-Iwoye.

Adedayo, T.O. 1995. 'The impact of trade liberalization on the production and marketing of cocoa in Ondo State'. MBA project submitted to the Department of Management and Accounting, Obafemi Awolowo University, Ile-Ife.

Adedoyin, S.F. 1999. 'Women-in-agriculture, national dynamics and agricultural development: Implication for development promotion in Nigeria', Nigerian Agriculture 3(2):27-30.

Akanji, B.O. 2002. 'Characteristics of the agricultural food market: Challenges and opportunities for small farmers and rural women'. Paper presented at the Regional Workshop on Promotion of Appropriate Agro-Processing Technologies in West Africa, Obafemi Awolowo University, Ile-Ife, $23^{\text {rd }}$ $26^{\text {th }}$, October.

Akinola, G. O. 2003. 'Gender factor in the marketing of cocoa in Ondo State'. M. Phil. Thesis submitted to the Department of Management and Accounting, Obafemi Awolowo University, Ile-Ife.

Aloba, O.R. 1999. 'Cocoa beans procurement and marketing activities in Atakumosa West local government of Osun State'. M.B.A. project submitted to the Department of Management and Accounting, Obafemi Awolowo University, Ile-Ife.

Awoyele, O.O. 1997. 'Procurement and marketing of cocoa products in South Western_Nigeria'. Project submitted to the Department of Economics, Obafemi Awolowo University, Ile-Ife.

Berar-Awad, A. 1989. Women and land. Report on the regional African workshop on women's access to land as a strategy for employment, promotion, poverty alleviation and household food security, International Labour Office in collaboration with the University of Zimbabwe, Harare, Zimbabwe, 17 to 21 October.

CBN. 1995. Annual reports and statement of accounts. Lagos: Central Bank of Nigeria.

FAO. 1985. Women in agriculture. Rome: Food and Agriculture Organisation.

FAO. 1997. Rural women and food security: Current situation and perspective. Rome: Food and Agriculture Organisation.

FOS. 1997. Gender inequalities: Socio-economic profile of women. Lagos: Federal Office of Statistics.

Haddad, L., Hoddinot, J. \& Alderman, H. 1994. Intrahousehold resource allocation: An overview. Washington, D.C: World Bank. Policy Research Working Paper 1255.
Holt, S.L. \& Ribe, H. 1991. Developing financial institutions for the poor and reducing barriers to access for women. Washington, D.C: World Bank. World Bank Discussion paper No 17.

ILO. 1989. Women and land. Report on the regional African workshop on women's access to land as a strategy for employment promotion, property aleviation and household food security, 17 - 21 October, Harare, Zimbabwe.

Jones, C. 1986. 'Intra-household bargaining in response to the introduction of new crops: A case study from North Cameroon.' In Moock, J.L. (Ed.), Understanding Africa's rural households and farming systems. Boulder, CO: Westview Press.

Kanbur, R. \& Haddad, L. 1994. 'Are better off households more unequal or less unequal?' Oxford Economic Papers, 46(3).

Kandiyoti, D. 1990. 'Women and rural development policies: The changing agenda', Development and Change 21(1): 5-22.

Kolawole, J. 2000. 'Collapsing rapidly: Nigeria's cocoa industry,' Nigerian Agriculture - Nigeria's Pioneer Agricultural News Reporting and Trade Promotion Magazine, 4(2): 8.

Kwesiga, J. C. 1998. 'Central yet peripheral: The rural women farmer and issues of African development'. IITA Seventh lecture in the distinguished African Scientist lecture Series, International Institute of Tropical Agriculture (IITA) Ibadan.

Moock, P. 1976. 'The efficiency of women as farm managers: Kenya', American Journal of Agricultural Economics, 58(5): 831-835.

Natsios, A. 2004. 'Women in development.' [online] URL http://www.usaid.gov/about/foia

Olatunbosun, D. \& Olayide, S. O. 1972. Trends in prospect for Nigerian commodity exports. Ibadan: N.I.S.E.R.

Olufokunbi, B. 1993. Marketing and successful living. IleIfe: Obafemi Awolowo University Press. Limited. Inaugural Lecture Series.

OSMARD. 2001. Produce Department Annual Grading Chart. Akure: Ondo State Ministry of Agriculture and Rural Development.

Owofemi, D. 1999. 'Cocoa marketing in Nigeria'. Paper presented at the Nigerian Cocoa Forum '99. The Cocoa Association of Nigeria (CAN) Akure, $15^{\text {th }}$ April.

Oyinloye, J.P. 1999. 'Cocoa marketing in Nigeria', Cocoa Association of Nigeria Bulletin, May. Secretariat of Cocoa Association of Nigeria (CAN), Akure.

Prodger, D. 1998. 'The land tenure system: A key factor', Courier ACP-EU, Brussels. 
QuickMBA 2004. 'Economics'. [online] URL:http:// www.quickMBA.com/econ/industry concentration.

Quisumbing, A.R. 1994. Gender differences in agricultural productivity: A survey of empirical evidence. Washington D.C: Education and Social Policy Department, The World Bank. ESP Discussion Paper Series Number 36.

Ramaswamy, S. 1991. 'Technological change, land use patterns and household income distribution in the Sahel The Burkina Faso case'. Ph. D. dissertation, Department of Economics, Purdue University, Lafayette.

Saito, K., Mekonnen, H. \& Spurling, D. 1994. Raising the productivity of women farmers in sub-Saharan Africa. Washington D.C: Africa Technical Department, World Bank. Africa Technical Department Series No. 230.

Schoemaker, A. 1996. 'Introduction to gender issues, definitions and concepts'. Proceedings of AGROTEC/FAO Workshop on Gender and Agricultural Engineering, Italy.

Thomas-Slayer, B. 1993. Tools of gender analysis. A guide to field methods for bringing gender into sustainable resource management. Worcester, MA: Clark University. ECOGEN Case Study Series, pp. 1-6.

Titilola, S.T. 1997. An econometric model for Nigeria's agricultural sector with emphasis on the future of cocoa in the Nigerian economy (1970-1990). Ibadan: N.I.S.E.R.

Udry, C., Hoddinot, J., Alderman, H. \& Haddad, L. 1995. 'Gender differentials in farm productivity: Implications for household efficiency and agricultural policy’, Food Policy 20(5): 407-423.

Weekes-Vagliani, W. 1985. 'Towards an analytical framework: Women, food self-sufficiency and food strategies'. In Femmes at Politiques Alimentaires; Actes du Seminaire Internationale, ORSTOM-CIE; 14 - 18 January, Paris, pp. 317-324.

Whitehead, A. 1990. 'Food production and food crisis in Africa'. In Wallace, T. \& March, C. (Eds.). Changing perceptions: Writing on gender and Development. Oxford: Oxfarm, pp. 68-77.

Wikipedia encyclopaedia. 2004. 'Gini coefficient'. [online] URL: http://en.wikipedia.org/wiki/Gini coefficient.

Yesufu, T.M. 1989. 'Marketing local products', Sunday New Nigerian, April 30: 8-9. 